\title{
TEKNOLOGI INFORMASI, PROFESIONALISME ACCOUNT REPRESENTATIVE DAN APLIKASI E-TAX TERHADAP PENERIMAAN PAJAK
}

\author{
LELY SURYANI, S.E., M.M. \\ Universitas Pamulang \\ *Email: lelysuryani80@yahoo.com
}

\begin{abstract}
Research on the effect of information technology, account representative professionalism and e-tax applications on tax revenue in the Pratama Tax Office in Kebayoran Baru Tiga. The sampling method and the use of primary data through random sampling. multiple linear regression is used in analyzing data. Each variable uses the validity test and reliability test so that the $r$ count $>r$ table and the Cronbach Alpha value> 0.60. The results of the normality test obtained 0.121. Partially, information technology has no effect on tax revenues, while account representative professionalism is positive, there is a significant and significant effect on tax revenue. Simultaneously, information technology and professionalism of account representatives have a positive and significant influence on tax revenue with fcount > ftabel.
\end{abstract}

Keywords : Information Technology, Account Representative Professionalism, Tax Receipts, E-Tax.

\section{PENDAHULUAN}

\section{Latar Belakang}

Usulan RAPBN Tahun Anggaran 2016 sedangkan Target APBN 2016 senilai Rp1.822,5 triliun, atau Rp25,6 triliun lebih kecil dibandingkan. Sumber Penghasilan ini dari pendapatan pajak Rp1.546,7 triliun dan pendapatan negara bukan pajak Rp273,8 triliun. Dari kisaran nominal data yang didapat ini membuktikan bahwa pemerintah sangat bergantung terhadap sektor pajak. Pajak merupakan salah satu sektor potensial yang mendukung pendapatan negara, karena di dalam sistem pengelolaannya melibatkan semua lapisan masyarakat sebagai subjek pajak yang memiliki peran besar dalam menghasilkan penerimaan dalam negeri. Dilihat dari laju pertumbuhan penduduk Indonesia yang bersumber dari Badan Pusat Statistik tahun 2010-2014 (4 tahun) sebesar 1,40\% yang pada tahun sebelumnya 2000-2010 (10 tahun) hanya 1,49\%. Alasan dilakukannya reformasi perpajakan terus menerus dikarenakan Negara ini butuh meningkatnya pendapatan, penerimaan, membentuk negara lebih baik dan perubahan mendasar 
menyeluruh di setiap sektor perpajakan yang sehingga kebijakan perpajakan dan sistem administrasi perpajakan mengarah ke lebih sempurna, agar daerah penghasilan pajak terbesar dapat semakin diperluas, sehingga titik daerah pendapatan pajak dapat maksimal dengan mengedepankan asas adil dan sosial dan memberikan pelayanan yang profesional kepada wajib pajak (Arifin, 2015:35). Konstruksi, penerapan, pembangunan, motivasi atau Sistem Informasi Manajemen berdasarkan komputer, khususnya pada aplikasi Hardware ,software inilah yang disebut dengan Teknologi Informasi. Direktorat Jenderal Pajak (DJP) yang diberi mandat oleh pemerintah Indonesia. DJP adalah sebuah pemerintahan yang mengumpulkan iuran pajak yang diterima dan melakukan perubahan yang lebih baik dalam rangka mencapai target yang telah ditetapkan. (Saputra dkk, 2014:2).

Adanya sistem administrasi pajak modern ini diharapkan lebih meningkatkan penerimaan pajak, baik dalam hal penerapan teknologi informasi, profesionalisme fiskus maupun pemanfaatan teknologi informasi berbasis electronik yang sesuai dengan Perencanaan yang dianggap strategis yang dilakukan Direktorat Jenderal Pajak tahun 2015 hingga 2019. Dengan memaksimalkan penerimaan pajak ini maka penerimaan negara pun juga maksimal karena semua penerimaan yang terdiri dari pajak dalam negeri dan pajak perdagangan internasional disebut dengan penerimaan perpajakan. Dengan demikian, KPP Pratama Kebayoran Baru Tiga menerapkan dan memanfaatkan teknologi informasi dan mengutamakan peranan account representative untuk meningkatkan kepatuhan wajib pajak sebagai upaya memaksimalkan pajak yang diterima. Dari permasalahan diatas maka peneliti tertarik mengulas dan membahas tentang "Pengaruh Penerapan Teknologi Informasi, Profesionalisme Account Representative dan Aplikasi E-Tax Terhadap Penerimaan Pajak".

\section{Perumusan Masalah Penelitian}

Berdasarkan fenomena yang ada pada latar belakang, maka peneliti menyimpulkan masalah sebagai bahan penelitian yang tersebut dibawah ini :

1. Apakah teknologi informasi dalam sistem administrasi perpajakan modern berpengaruh terhadap penerimaan pajak?

2. Apakah profesionalisme account representative berpengaruh terhadap penerimaaan pajak?

3. Apakah aplikasi -tax berpengaruh terhadap penerimaan pajak?

4. Apakah penerapan teknologi informasi, profesionalisme account representative dan aplikasi $e$-tax secara bersama-sama berpengaruh terhadap penerimaan pajak? 


\section{Tujuan Penelitian}

1. Agar dapat diketahui dan memberi bukti empiris pengaruh teknologi informasi dalam sistem administrasi perpajakan terhadap penerimaan pajak,

2. Agar dapat diketahui dan memberi bukti empiris pengaruh profesionalisme account representative terhadap penerimaan pajak,

3. Agar dapat diketahui dan memberi bukti empiris aplikasi $e$-tax berpengaruh terhadap penerimaan pajak.

4. Agar dapat diketahui dan memberi bukti empiris pengaruh penerapan teknologi informasi, profesionalisme account representative dan aplikasi $e$ tax terhadap penerimaan pajak.

\section{Manfaat Penelitian}

1. Bagi Akademisi sebagai pedoman akademisi dalam rangka sebagai referensi dan acuan dalam penelitian selanjutnya.

2. Bagi perusahaan (Kantor Pajak Pratama Kebayoran Baru Tiga), sebagai tolak ukur dan perbaikan sistem pajak administrasi modern berbasis teknologi informasi yang telah diimplementasikan di KPP Kebayoran Baru Tiga agar lebih dapat berbenah diri dan melakukan pembaharuan disetiap lini dalam rangka menuju kesempurnaan pelayanan berbasis IT.

\section{LANDASAN TEORI}

\section{Teori Technology Acceptance Model (TAM)}

Model penerimaan teknologi (Technology Acceptance Model/TAM) (Ratsidyaningtyas, 2016:2) adalah teori mengenai penggunaan sistem informasi di mana diakui memiliki pengaruh dan secara garis besar diimplementasikan guna memaparkan pendapatan setiap individu. Oleh Davis Model penerimaan teknologi atau TAM (Technology Acceptance Model) dikenalkan tahun 1989 adalah penyesuaian dari teori tindakan beralasan atau Theory Reasoned Action (TRA), teori ini menyatakan seseorang di dalam menggunakan sistem dalam melakukan suatu aktivitas atau kegiatan maka karena dianggap dapat menimbulkan suatu yang berarti bagi seseorang tersebut.

\section{Pajak}

UU RI Nomor 16 tahun 2009, suatu penyertaan wajib bagi masyarakat Indonesia yang diimplementasikan dengan uang dan dipungut dengan nominal tertentu bagi perorangan maupun badan usaha , namun tidak merasakan manfaat langsung namun iuran tersebut digunakan untuk keperluan umum dalam rangka memakmurkan rakyat. 
Essay in Taxation dalam buku Prof. Edwin R.A. Seligman yang diterbitkan di Amerika Serikat menyatakan: "Tax is Compulsary Contribution from the person, to the government to depray the expenses incurred in the common interest of all, without reference to Special benefit Conferred". Dapat diartikan bahwa adanya pungutan yang dipaksakan dari individu dan badan usaha kepada negara dalam rangka dimanfaatkan untuk segala sesuatu pengeluaran negara yang berkaitan dengan warga negara tanpa penyertaan untuk digunakan atau memberikan suatu keuntungan yang menuju khusus kepada individu sebagai timbal balik (Anwar, 2014:29).

\section{Profesionalisme Account Representative}

Profesionalisme merupakan bahasa tubuh dan etika seorang manusia di mana melakukan profesi tertentu. Pengertian secara umum, bahwa orang dapat dikatakan professional bila orang tersebut memiliki keahlian dalam melaksanakan pekerjaannya atau profesi yang memiliki standar baku di bidang keahlian yang bersangkutan dan menjalankan tugasnya dengan mematuhi etika maupun attitude yang telah ditetapkan. Hiro Tugiman (2009)

Account Representative (AR) merupakan pekerja yang diangkat pada Kantor Pelayanan Pajak dinamai berdasarkan PMK Nomor 79/PMK.01/2015. Account representative berfokus pada suatu kegiaatan, hal ini sesuai dengan Nomor KEP-178/PJ/2004 tentang Cetak Biru (blue print) Kebijakan Direktorat merupakan Keputusan Direktorat Jenderal Pajak Tahun 2001-2010. Kewajiban dalam melakukan suatu pengawasan agar para wajib pajak patuh dalam hal membayar pajak, mengimplementasikan bimbingan dan informasi berupa saran kepada wajib pajak merupakan suatu kewajiban Account Representative (AR). Setiap Account Representative (AR) mempunyai wewenang dalam mengawasi sejumlah wajib pajak Atas dasar macam kegiatan usaha dalam rangka menciptakan kinerja yang menuju profesionalisme dan dalam rangka mencapai produktivitas kinerja dikarenakan dalam implementasi sebuah tugas agar dapat lebih terarah dan tertuju, inilah salah satu tugas dari pada pelayanan yang dilakukan seorang Account Representative (AR).

Dengan menerbitkan sebuah profil wajib pajak yang berfungsi sebagai Pedoman acuan dalam tahapan pertama implementasi pendataan dan pemeriksaan pajak, fungsi seorang Account Representative (AR) berkewajiban memberikan pelayanan maksimal kepada setiap masyarakat ataupun warga negara yang membayar pajak sangat dibutuhkan dan adanya pemberlakuan sistem Account Representative (AR) merupakan sebuah bukti bahwa pelayanan yang maksimal kepada wajib pajak, Hal ini sangat diharapkan dapat mengoptimalkan tingginya pajak yang diterima atas segala kegiatan intensifikasi wajib pajak. 
Dengan demikian sebuah kegiatan pemeriksaan dilakukan kelak, dapat berkelanjutan dengan terarah serta berkualitas dan memiliki tolak ukur yang akurat sehingga maksimal hasil yang diperoleh. mengenai Organisasi dan Tata Kerja Instansi Vertikal Direktorat Jenderal Pajak yang ditetapkan pada tanggal 17 Oktober 2014 diatur dalam PMK Nomor 206.2/PMK.01/2014. Pemisahan kerja account representative, seksi pengawasan dan konsultasi I menjalankan fungsi pelayanan dan konsultasi pajak, sedangkan seksi pengawasan dan konsultasi II, II, dan IV menjalankan fungsi pengawasan dan penggalian potensi wajib pajak. Hal ini diatur dalam pasal 57 PMK Nomor 206.2/PMK.01/2014

\section{Penerimaan Pajak}

Negara dalam hal menerima pajak dari warga negaranya bersifat fluktuatif tergantung dari perkembangan ekonomi dan kegiatan usaha bagi setiap warga negaranya. Sumber dari penerimaan pajak adalah semua penerimaan yang terdiri dari pajak dalam negeri dan pajak perdagangan internasional. $\mathrm{PPh}$ atau pajak penghasilan perorangan ataupun badan, PPN atau pajak pertambahan nilai barang dan jasa, PPnBM atau Pajak Penjualan atas Barang Mewah, PBB atau pajak bumi dan bangunan atas perkebunan, pertanian, pertambangan, BPHTB, cukai merupakan pajak yang diterima negara yang bersumber dari dalam negeri. Sedangkan segala yang diterima negara yang berasal dari bea masuk potput ekspor merupakan pajak perdagangan internasional. Struktur pendapatan negara melebihi $50 \%$ diterima dari hasil penerimaan perpajakan, dari sektor nonmigas memiliki sumbangsih terbesar dalam peran sertanya menyetorkan pajak ke negara

Adapun berbagai macam hal yang dapat dilakukan dalam rangka memaksimalkan penerimaan pajak:

1. Undang Undang yang diterapkan didalam sebuah negara haruslah jelas dan pasti dan diputuskan secara resmi, pajak yang dipungut harus mengacu pada undang undang agar keadilan dapat digapai. Akan tetapi, adanya undangundang artinya belum memadai. Perlunya kejelasan Undang-undang, tidak rumit dan mudah dimengerti fiskus ataupun petugas pajak itu sendiri, dan yang membayar pajak. Kericuhan akan menguap apabila munculnya salah tafsir dan salah persepsi tentang tata cara pemungutan pajak yang mengakibatkan pembayaran dan pemungutan pajak mengalami kendala.

2. wajib pajak wajib mengisi dan menyampaikan Surat Pemberitahuan dengan benar, lengkap, jelas, dan menandatanganinya merupakan bunyi UndangUndang No. 16 Tahun 2009 Pasal 4 ayat (1). Sedangkang Pasal 12 ayat (1): surat ketetapan pajak bukan acuan bagi setiap wajib pajak dalam memenuhi keawjibannya terhadap pajak yang terutang namun berdasarkan undangundang pajak. Di dalam undang undang diatas dijelaskan bahwa negara kita sejak tahun1984 menganut sistem self assement yakni, pengisian Surat 
Pemberitahuan (SPT) dalam dilakukan oleh pembayar pajak pada setiap periode tertentu yang telah ditentukan. Kemudian fiskus melakukan pemeriksaan atas kebenaran SPT yang telah diisi sendiri oleh pembayar pajak tersebut. Pemahaman atas undang undang mengenai perpajakan sangat lah penting dalam rangka melakukan tugas administrasi perpajakan. Dengan demikian, profesionalisme dan intelektualitas sangat berarti dalam rangka tercipta warga negara yang menyadari betapa pentingnya pajak dan ingin melaksanakan tugasnya. inilah perlunya undang undang yang dapat dimengerti dan dapat dipahami oleh seluruh lapisan masyarakat yang dimana undang undang tersebut tidak menimbuklkan multi tafsir bagi fiskus maupun masyarakat.

3. Profesionalisme dan skill fiskus (Petugas Pajak). Sangat menentukan betapa effektif dan effisiennya penerapan undang undang dalam hal implementasi pajak. Berkaitan dengan profesionalisme yang memiliki skill yang mumpuni, cakap, integritas dan menguasai teknikal ini dapat mempengaruhi dalam pendapatan pajak yang optimal.

4. Tepatnya dalam penerapan Sistem Administrasi pajak. Optimalnya pendapatan pajak yang diterima tergantung bagaimana cara memungutnya. Menurut Smith (1901), ada empat azas pemungutan pajak: Equity/Equality azas adil merupakan hal yang utama dalam sistem pajak. Artinya negara harus adil dalam pemungutan pajak . Certainty, pembayar pajak tidak boleh ditutupi transparansi (certain) dan tidak kongkalingkong (not arbitrary). peraturan ditegakan disini mana subjek dan mana sumber pajak, berapa besarnya kewajiban pajak dan bagaimana aturan dalam pembayaran pajak tersebut. Convenience pada saat penghasilan didapatkan maka pada saat itulah waktu yang baik dalam pemungutan pajak. Economy, biaya dalam hal terjadinya pemungutan pajak yakni dibawah penghasilan daripada yang diterima sipembayar pajak.

\section{Aplikasi $E$-Tax}

E-Tax merupakan sistem dan teknologi informasi yang dapat dimanfaatkan dalam situasi saat ini. E-tax cash management adalah di mana data pajak orang pribadi atau badan yang dikirim secara online pada kas negara (Sari, 2014:12). Peraturan KEMENKEU Republik Indonesia Nomor 115/PMK.05/2017 yakni Teknologi informasi yang memanfaatkan elektronik (e-tax) dimana diatur di Sistem Penerimaan Negara Secara Elektronik. Hal ini memberikan suatu value yang positif. Electronic Tax yakni mengoptimalkan komunikasi dua arah mengenai sistem administrasi perpajakan yang dapat menguntungkan dua belah pihak antar internal dan eksternal kantor pajak 


\section{Hipotesis}

Sugiyono (2016:64), jawaban yang hanya bersifat sementara dalam sebuah penelitian sebagai acuan yang akan diuji kebenarannya ini dinamakan hipotesis. Adapaun hipotesi yang dikemukakan berdasarkan rumusan masalah dan alur pemikiran si peneliti adalah sebagai berikut:

1. Hipotesis teknologi informasi terhadap penerimaan pajak

Delli Maria (2013) menjelaskan tuntutan akan peningkatan penerimaan,perlunya reformasi perpajakan dari berbagai aspek dalam rangka agar sistem dan kebijakan tentang pajak dapat lebih sempurna dari masa ke masa agar basis pajak yang luas dapat tertib administrasi sehingga mengoptimalkan pendapatan pajak. Pemanfaatan teknologi informasi menurut Thompson et,al., (1991) dalam Idah jubaedah (2015) tekhnologi yang berguna yang dapat mempermudah individu dalam menyelesaikan pekerjaannya.

Atas dasar dua jurnal yang dikemukan maka dapat simpulkan teknologi informasi administrasi pajak modern yang tersistem memiliki fungsi memaksimalkan pajak yang diterima dengan hipotesis, yaitu :

$\mathrm{H}_{1}$ : Diduga ada pengaruh implementasi teknologi informasi terhadap penerimaan pajak,

2. Hipotesis profesionalisme account representative terhadap penerimaan pajak. Nofryanti (2014) mengatakan tax area salah satu indikator yang berperan utama mengoptimalkan penghasilan negara. Peraturan-peraturan perpajakan yang diterbitkan oleh Menteri Keuangan yakni diantaranya dengan membuat account representative pada KPP dan kantor pelayanan pajak.

Yuditya (2014) secara parsial kemampuan dan kapabilitas account representative dapat mempengaruhi secara signifikansi atas aturan main dalam keamanan pajak yang dipungut oleh Kanwil Direktorat Jenderal Pajak DIY. Atas dasar unkapan kutipan jurnal diatas, maka account representative adalah suatu upaya pemerintah untuk mengoptimalkan penerimaan pajak dari sisi intensifikasi perpajakan Indonesia.

$\mathrm{H}_{2}$ : Diduga ada pengaruh profesionalisme account representative terhadap penerimaan pajak

3. Hipotesis aplikasi $e$-tax terhadap penerimaan pajak

Finny Tania Rachdianti (2016) e-tax dengan cara self assessment system dalam rangka memudahkan pembayaran pajak secara online. salah satu sarana E-Tax dalam rangka perkembangan sistem dan teknologi informasi. Sedangkan Dara Ayu Mentari (2016) metode e-billing berpengaruh signifikansi terhadap penerimaan pajak. Castrio (2016) hadirnya E-Tax Pembayar pajak diberi kemudahan setiap hendak membayar atau pelaporan tanpa harus mengantri di bank dan di kantor pos sehingga memudahkan 
dalam pembayaran setoran pajak secara cepat, praktis, dan akurat dengan meminimalisir batasan biaya, ruang dan waktu melalui jaringan internet secara online.

Berdasarkan pemaparan diatas penerapan aplikasi dengan adanya $e$-tax, maka teknologi informasi menjalankan fungsinya dengan baik. Selain itu penerapan $e$-tax berpengaruh kepada kepatuhan pembayar pajak dan dapat memaksimalkan pajak yang diterima.

$\mathrm{H}_{3}$ : Diduga aplikasi $e$-tax berpengaruh terhadap penerimaan pajak.

4. Hipotesis teknologi informasi, profesionalisme account representative dan aplikasi $e$-tax berpengaruh terhadap penerimaan pajak

Dikarenakan rendahnya di Indonesia akan patuhnya wajib pajak dimana menyebabkan penerimaan negara dari sektor perpajakan tidak tercapai targetnya. Direktorat Jendral Pajak terus membenahi kualitas-kualitas layanan untuk para wajib pajak agar dapat pembayar pajak yang tertib ditingkatkan, sehingga negara yang terima pendapatan dari sub pajak tiap tahunnya mencapai targetnya dan mengalami kenaikan, salah satunya dengan reformasi perpajakan. Apriliana (2013) dalam Febrian (2015) membuktikan bahwa administrasi sistem pajak yang modern berpengaruh yang positif dan signifikan pada pembayar pajak yang patuh. administrasi sistem pajak menuju kesempurnaan untuk meningkatnya layanan kepada pembayar pajak menggunakan berbagai informasi teknologi sehingga harapan dapat meningkatkan wajib pajak patuh dan pajak yang diterima, maka dikatakan. administrasi perpajakan modern Said (2017) mengatakan bahwa denga adanya kualitas layanan yang dioptimalkan maka AR dalam pemisahan fungsi agar wajib pajak dapat dilayani secara optimal. Dengan adanya AR merupakan beberapa alternafif pemerintah dalam menerima pajak lebih optimal.

Berdasarkan pemaparan diatas, secara simultan informasi teknologi profesionalisme account representative dan Aplikasi E-Tax dapat memberikan pengaruh terhadap penerimaan pajak.

$\mathrm{H}_{4}$ : Diduga teknologi informasi, profesionalisme account representative dan Aplikasi E-Tax secara simultan memiliki pengaruh terhadap pajak yang diterima.

\section{METODE PENELITIAN}

\section{Populasi}

(Sugiyono, 2016:80). sekumpulan area yang umum yang terdiri dari Pelaku dan objek dimana memiliki integritas dan ciri ciri tertentu dimana penelitilah yang 
menentukannya untuk dipelajari dan disimpulkan merupakan sebuah populasi. Populasi dipenelitian ini adalah seluruh wajib pajak yang saat ini ada di arsip KPP Pratama Kebayoran Baru Tiga yaitu sebanyak 23.146 orang.

\section{Sampel}

(Sugiyono, 2016:81). Sampel merupakan sebahagian entitas dan karakteristik dari populasi tersebut metode random sampling digunakan dalam pemilihan sampel pada penelitian ini. (Sugiyono 2016, 82).Secara acak anggota sampel diambil dari populasi dengan perlakuan tanpa memperlihatkan strata dan semua populasi dianggap sama dengan tujuan untuk mendapatkan sampling yang representative.

Sample diambil berdasarkan rumus Solvin. Adapun rumus Solvin adalah :

$$
S=\frac{(\text { ) }}{S}
$$

Keterangan :

$\mathrm{S}=$ Ukuran Sampel

$\mathrm{N}=$ Ukuran Populasi

$\mathrm{E}=$ persen kelonggaran ketidak telitian karena kesalahan

Sampel yang diambil dan ditoleransi sebesar $10 \%$

$\mathrm{S}$

$$
\begin{aligned}
& =\frac{\cdot(\cdot)}{\cdot(,)} \\
& =\frac{\cdot}{\cdot} \\
& =\frac{\cdot}{\cdot} \\
& =99,56 \text { menjadi } 100
\end{aligned}
$$

\section{Teknik Pengumpulan Data}

\section{Kuesioner}

(Sugiyono, 2016:142). Beberapa pertanyaan atau pernyataan kepada orang lain agar orang tersebut memberikan jawaban dan orang tersebut dijadikan responden merupakan salah satu tehnik pengumpulan data yang dinamakan dengan kuisioner, Penilitian ini kuesioner diberikan kepada pembayar pajak dimana termasuk sebagai pembayar pajak yang ada pada KPP Pratama Kebayoran Baru Tiga, Jakarta.

skala likert digunakan sebagai pilihan jawaban dalam kuisioner ini. Gradiasi setiap item instrumen dimulai dari yang sangat tidak setuju hingga ke jenjang sangat setuju. analisis kuantitatif di perlukan, sehingga diberi skor atas jawaban yang dipilih : 


\section{Tabel 3.1 Alternative jawaban dengan skala likert}

\begin{tabular}{|c|c|c|}
\hline Simbol & $\begin{array}{c}\text { Alternative } \\
\text { Jawaban }\end{array}$ & Nilai \\
\hline SS & Sangat Setuju & 5 \\
\hline S & Setuju & 4 \\
\hline R & Ragu-ragu & 3 \\
\hline TS & Tidak Setuju & 2 \\
\hline STS & $\begin{array}{c}\text { Sangat Tidak } \\
\text { Setuju }\end{array}$ & 1 \\
\hline
\end{tabular}

\section{Dokumentasi}

Adalah suatu catatan ataupun fenomena yang telah terjadi sehingga biasanya seperti artikel, karya tulis, foto atau karya yang memiliki kesan dan ingatan dari individu. Arsip berupa karya tulis dapat diumpamakan note, cerita hidup, kisah, undang undang dan keputusan (Sugiyono, 2016:240). Penelitian ini menghasilkan dokumen berupa laporan penerimaan pajak pada KPP Pratama Kebayoran Baru Tiga selama 6 tahun (2011-2016).

\section{Studi Kepustakaan}

(Nazir,1988:111). Studi pustaka pemahaman dan pembelajaran terhadap buku-buku, litertur-literatur, catatan-catatan, dan laporan-laporan yang keterkaitan dengan suatu masalah yang ingin diambil kesimpulannya . Penulis dalam meneliti melakukan suatu cara mencoba untuk membaca dan memeahami literatur telah tersedia kaitannya dengan masalah dijadikan sebagai bahan yang hendak diteliti.

Jurnal peneliti sebelumnya yang ada kaitannya dengan penelitian ini diteliti sebagai tudi pustaka dengan cara di telaah dan di pahami.

\section{Teknik Analisis}

Penelitian ini menggunakan tekhnik analisisi yang mana menggunakan analisis kuantitatif. Penelitian yang bersifat kuantitatif, data dianalisa setelah semua data dari para pemberi data dikumpulkan. Analisis data menggunakan tekhnik statistik deskriptif. (Sugiyono, 2016:147).

\section{Statistik Deskriptif}

(Sugiyono, 2016:147). Menggunakan gambaran dan menganalisa data melalui cara mendeskripsikan data yang telah terkumpul tidak untuk disimpulkan secara umum, inilah yang dimaksud Statistik deskriptif. Adapun yang dideskriftifkan antara lain tentang sbuah demografi para pemberi data misalkan usia,jenis kelamin, pendidikan terakhir, pekerjaan. 


\section{Uji kualitas data}

Uji yang menggunakan alatnya yakni seorang konsumen atau individu, yang bertujuan data yang diberikan oleh konsumen dapat diminta tanggung jawabnya. uji validitas dan uji reliabilitas lah yang digunakan.

1. Uji validitas

Barometer kuisioner tersebut diterima atau ditolak maka diperlukannya uji validitas. (Ghazali, 3013:52). Dikatakan diterima kuisioner tersebut dan absah hal hal yang ditanya dalam kuisioner tersebut berisikan atau memiliki kaitan yang hendak diteliti oleh peneliti. Priyatno (2016:150) menjelaskan metode keputusan apa yang diambil untuk uji validitas sebagai berikut :

1) Atas dasar signifikansi

- Nominal signifikansi > 0,05 maka butir disimpulkan tidak valid

- Nominal signifikansi $<0,05$ maka butir disimpulkan valid

2) Berdasarkan nilai korelasi

- Nominal $r$ hitung $<r$ tabel butir disimpulkan tidak valid

- Nominal $r$ hitung $>r$ tabel butir disimpulkan valid

2. Uji reliabilitas

Untuk melihat konsistensi sebuah instrument pengukuran, apakah konsisten atau belum bila dilakukan pengulangan pengukuran. Instrument kuesioner belum dinyatakan tidak dapat digunakan atau tidak digunakan (Priyatno, 2016:154). Penggunaan Uji reliabilitas penelitian dengan metode Cronbach Alpha. uji reliabilitas dengan batasan 0,6. Sekaran (1992) dalam buku Priyatno (2016:158) reliabilitas $<0,6$ tidak baik, bila 0,7 diterima dan diatas 0,8 kategori baik.

\section{Uji asumsi klasik}

(Priyatno, 2016:117). hasil estimasi regresi agar diketahui sungguh terlepas heteroskedastisitasnya, memerlukan multikolinearitas, autokorelasi dan uji asumsi klasik. uji normalitas, uji multikolinearitas dan uji heteroskedastisitas digunakan dalam uji asumsi klasik.

\section{Uji Normalitas}

Bertujuan menguji regresi variabel sebagai gangguan atau residual distribusi normal. Walaupun variable normal tidak semestinya perlu dalam analisis akan tetapi baik jika semua variabel berdistribusi normal (Ghazali, 2013:30).

Histogram, P-plot dan Kolmogorov Smirnov, digunakan dalam Uji normalitas dalam penelitian ini. Metode pengambilan keputusan untuk uji normalitas yaitu data dikatakan normal apabila gambar pada histogram membentuk P-Plot memperlihatkan titik-titik pada gambar mengikuti dan tidak jauh dari garis diagonal. Selain itu, pada tabel Kolmogorov Smirnov jika 
tersignifikansi > 0,05 maka data residual berdistribusi normal dan tersignifikansi $<0,05$ data residual distribusi tidak normal.

2. Uji Multikolinearitas

(Ghazali, 2013:105). Bertujuan menguji apakah regresi memiliki korelasi antar variabel bebas (independen) Metode pengambilan keputusan yaitu dapat dilihat dari tabel Coefficients jika batas tolerir $>0,1$ dan VIF $<10$ multikolinearitas tidak ada.

3. Uji Heteroskedastisitas

Bertujuan diujinya model regresi terjadi perbedaan variasi dari residual satu observasi ke observasi lain (Sugiyono, 2013:139). Metode keputusan yang diambil dalam uji heteroskedastisitas menggunakan scatterplot yaitu ditemuinya titik tersebar bentuk tak menentu atas bawah 0 disumbu $\mathrm{Y}$ hal ini tidak heteroskedastisitas gaya regresi (Priyatno, 2016:139). Untuk lebih memastikan lolos atau tidaknya uji heteroskedastisitas dapat menggunakan uji gletser yaitu dengan melihat tabel coefficients dengan variabel absolut. Syarat dikatakan lolos uji heteroskedastisitas adalah nilai Sig harus di atas 0,05 ( > $0,05)$.

\section{Uji Hipotesis}

2. Uji Regresi Linier Berganda

Merupakan cara statistik bermanfaat memeriksa dan merancang adanya kaitan variable. Regresi berganda kerap dimanfaatkan untuk menghadapi masalah analisis regresi yang melibatkan kaitan beberapa variabel bebas. Secara spesifik gaya persamaannya adalah :

$\mathrm{Y}=\mathrm{a}+\mathrm{b}_{1} \mathrm{X}_{1}+\mathrm{b}_{2} \mathrm{X}_{2}+\mathrm{e}$

Keterangan :

$\mathrm{Y} \quad=$ Variabel terikat

a $\quad=$ Kontanta

$\mathrm{b}_{1}, \mathrm{~b}_{2}=$ Koefisien regresi

$\mathrm{X}_{1}$ dan $\mathrm{X}_{2}=$ Variabel bebas

$\mathrm{e} \quad=$ Error (kesalahan pengganggu)

2. Uji Koefisien Korelasi (R)

Bertujuan hubungan kekerabatan arah hubungan dan mengetahui sangat erat atau tidak hubungan tersebut (Priyatno, 2016:40).

Dasar ukuran kuat lemahnya hubungan antar dua variabel penulis menggunakan pedoman dari Sugiyono dalam Priyatno (2016:44). Dasar untuk penilaian koefisien korelasi sebagai berikut : 
Tabel 3.2 Dasar untuk memberikan Penilaian koefisien korelasi

\begin{tabular}{|c|c|c|}
\hline NO & Interval Koefisien & $\begin{array}{c}\text { Tingkat } \\
\text { Hubungan }\end{array}$ \\
\hline 1 & $0,00-0,199$ & Sangat rendah \\
\hline 2 & $0,20-0,399$ & Rendah \\
\hline 3 & $0,40-0,599$ & Sedang \\
\hline 4 & $0,6-0,799$ & Kuat \\
\hline 5 & $0,80-1,000$ & Sangat kuat \\
\hline
\end{tabular}

Sumber : Priyatno (2016:44)

3. Uji Koefisien Determinasi $\left(\mathrm{R}^{2}\right)$

Uji Koefisien Determinasi $\left(\mathrm{R}^{2}\right)$ pada intinya melakukan pengukuran sampai mana titik jauh kapabilitas gaya dalam menjelaskan macam variabel yang bergantung dengan variable lain. Angka koefisien determinasi antara 0 dan 1. Utamanya kekurangan dalam penggunaan koefisien determinasi umum pada total varian yang tidak bergantung pada varian lain yang dimasukkan kedalam model. Tiap penambahan satu variabel independen, makan $\mathrm{R}^{2}$ bertambah tanpa melihat apakah variabel tersebut berpengaruh secara signifikan terhadap variabel dependen. Sehingga, beberpa orang meneliti menyarankan memakai nilai Adjusted $R^{2}$ ketika mengevaluasi tekhnik atau gaya yang terbaik (Ghazali, 2013:97).

4. Uji Statistik t (uji parsial)

Ghazali, (2013:98) mengatakan, sebagai petunjuk berapakah banyak yang dipengaruhi 1 varian penjelas secara sendiri dalam menjelaskan variabel dependen, inilah dinamakan Uji t-statistik, di mana;

$\mathrm{H}_{0}$ : Variabel independen sebagian tidak mempengaruhi variabel dependen

$\mathrm{H}_{\mathrm{a}}$ : Variabel independen sebagian mempengaruhi variabel dependen

Pengambilan keputusan (Priyatno, 2016:67-68) :

1) Berdasarkan nilai signifikansi

Signifikansi $>0,05$ jadi $\mathrm{H}_{0}$ dterima

Signifikansi $\leq 0,05$ jadi $\mathrm{H}_{0}$ ditolak

2) Berdasarkan $t$ hitung dan $t$ tabel

$\mathrm{t}$ hitung $\leq \mathrm{t}$ tabel atau $-\mathrm{t}$ hitung $\geq$ - $\mathrm{t}$ tabel jadi $\mathrm{H}_{0}$ diterima

$\mathrm{t}$ hitung $>\mathrm{t}$ tabel atau $-\mathrm{t}$ hitung $<-\mathrm{t}$ tabel jadi $\mathrm{H}_{0}$ ditolak

5. Uji Simultan (Uji F)

(Ghazali, 2013:98). Bila semua variabel penjelas mampu mempengaruhi variabel dependen/terikat maka dikatakan Uji Simultan(Uji F) Pengambilan keputusan (Priyatno, 2016:64-65)

1) Berdasarkan nilai signifikansi

Signifikansi $>0,05$ jadi $\mathrm{H}_{0}$ diterima 
Signifikansi $\leq 0,05$ jadi $\mathrm{H}_{0}$ ditolak

2) Berdasarkan $F$ hitung dan $F$ tabel

$\mathrm{F}$ hitung $<\mathrm{F}$ tabel jadi $\mathrm{H}_{0}$ diterima

$\mathrm{F}$ hitung $>\mathrm{F}$ tabel jadi $\mathrm{H}_{0}$ ditolak

\section{ANALISIS HASIL}

\section{Uji Kualitas Data}

Diketahui nilai Klomogorov Smirnov 0,080 dan nilai signifikansi pada Unstandardized Residual sebesar 0,121 (>0,05). Oleh karena nilai signifikansi lebih besar dari 0,05 , maka diartikan bahwa data berdistribusi normal. Nilai tolerance masing-masing variabel $>0,1$ dan nilai VIF masing-masing variabel < 10, maka dapat disimpulkan bahwa pada model regresi ini tidak terjadi multikorelasi. Demikian juga nilai semua variabel lebih besar dari 0,05, maka dapat disimpulkan bahwa model regresi ini tidak terjadi heteroskedastisitas.

\section{Uji Hipotesis}

\section{Uji Regresi Linier Berganda}

Persamaan regresi yang terbentuk adalah sebagai berikut :

$$
\mathrm{Y}
$$$$
=\alpha+\beta_{1} X_{1+} \beta_{2} X_{2}+\beta_{3} Z+e
$$$$
=3,270+(-0,153) X_{1}+0,474 X_{2}+0,592 Z+e
$$$$
=3.270+(-0,153) \text { Penerapan Teknologi Informasi }+0,474
$$
Profesionalisme Account Representative + 0,592 Penerapan ETax

Dari persamaan regresi linier diatas dapat diartikan sebagai berikut :

1. Nilai koefisien konstanta $(\alpha)$ adalah positif sebesar 3,270 yang mengandung arti bahwa jika variabel dependen dianggap sebagai konstanta, maka nilai penerimaan pajak sebesar 3,270.

2. Nilai koefisien regresi penerapan teknologi informasi dalam sistem administrasi perpajakan modern sebesar $-0,153$. Hal ini mempunyai arti bahwa penerapan teknologi informasi dalam sistem administrasi perpajakan modern tidak mempunyai pengaruh yang searah terhadap penerimaan pajak dan jika setiap kenaikan 1 satuan penerapan teknologi informasi dalam sistem administrasi perpajakan modern maka penerimaan pajak akan berkurang sebesar 0,153 .

3. Nilai koefisien regresi profesionalisme account representative sebesar 0,474. Hal ini mempunyai arti bahwa profesionalisme account representative mempunyai pengaruh yang searah terhadap penerimaan pajak dan jika setiap kenaikan 1 satuan profesionalisme account representative maka akan meningkatkan penerimaan pajak sebesar 0,474.

4. Nilai koefisien regresi penerapan e-tax sebesar 0,592. Hal ini mempunyai arti bahwa penerapan aplikasi $e$-tax mempunyai pengaruh yang searah terhadap 
penerimaan pajak dan jika setiap kenaikan 1 satuan penerapan aplikasi $e$-tax maka akan meningkatkan penerimaan pajak sebesar 0,592.

\section{Uji Koefisien Korelasi}

Koefisien korelasi merupakan nilai untuk mengukur kuatnya hubungan antar variabel independen dengan variable dependen. Koefisien korelasi berganda dinyatakan dengan symbol " $r$ ". untuk meningkatkan kembali nilai korelasi antar kedua variabel sampai dengan 1 . Untuk melihat kuat atau lemahnya hubungan antar variabel independen dan dependen, $\mathrm{R}$ menunjukan nilai 0,838 . Interpretasi koefisien korelasi pada interval 0,80-1,000. Hal ini menunjukan bahwa terdapat hubungan yang sangat kuat antara variabel penerapan teknologi informasi $\left(\mathrm{X}_{1}\right)$,profesionalisme account representative $\left(\mathrm{X}_{2}\right)$, penerapan e-tax $(\mathrm{Z})$, interaksi antara penerapan teknologi informasi dan penerapan e-tax $\left(\mathrm{X}_{1} * \mathrm{Z}\right)$ dan interaksi antara profesionalisme account representative dan penerapan e-tax $\left(\mathrm{X}_{2} * \mathrm{Z}\right)$ terhadap penerimaan pajak (Y).

\section{Uji Koefisien Determinasi $\left(\mathbf{R}^{2}\right)$}

Koefisien determinasi digunakan untuk mengetahui seberapa besar kemampuan variabel independen dalam menerangkan variabel dependen. Nilai determinasi terlihat dari nilai Adjusted $R$ Square. Hasil pengujian koefisien determinasi adalah sebagai berikut :

nilai Adjusted $R$ Square sebesar 0,686. Dari hasil tersebut dapat diartikan bahwa $68,6 \%$ variabel penerimaan pajak dapat dijelaskan oleh variabel penerapan teknologi informasi $\left(\mathrm{X}_{1}\right)$, profesionalisme account representative $\left(\mathrm{X}_{2}\right)$, penerapan e-tax (X3). Sedangkan sisanya sebesar 31,4\% (100\%-68,6\%) dijelaskan oleh factor-faktor lain yang tidak dimasukkan dalam model regresi.

\section{Uji Statistik t (parsial)}

Uji t dilakukan untuk mengetahui seberapa besar pengaruh penerapan teknologi informasi dalam sistem administrasi perpajakan modern $\left(\mathrm{X}_{1}\right)$ terhadap penerimaan pajak (Y), kemudian untuk mengetahui seberapa besar profesionalisme account representative $\left(\mathrm{X}_{1}\right)$ terhadap penerimaan pajak $(\mathrm{Y})$ uji t dapat dinilai dengan menggunakan SPSS 22 dimana df (degree of freedom) atau derajat kebebasan sebesar $\mathrm{df}=100-4=96$ maka t tabel adalah 1,98498 . Selain itu, untuk menilai uji t dapat dilihat dari nilai signifikansi. Nilai signifikansi harus kurang dari $0,05(<0,05)$.

Hasil uji t menunjukan bahwa signifikan pengaruh penerapan teknologi informasi dalam sistem administrasi perpajakan modern terhadap penerimaan pajak yang didapat sebesar $-1,297<1,98498$ dan memiliki nilai signifikan sebesar $0,198>0,05$. Hal ini berarti $\mathrm{H}_{1}$ ditolak dan dapat dikatakan bahwa penerapan teknologi informasi dalam sistem administrasi perpajakan modern tidak berpengaruh terhadap penerimaan pajak.

Pengaruh profesionalisme account representative terhadap penerimaan pajak yang didapat sebesar 4,623>1,98498 dan memiliki nilai signifikan sebesar $0,000<0,05$. Hal ini berarti $\mathrm{H}_{2}$ diterima dan dapat dikatakan bahwa 
profesionalisme acoount representative berpengaruh signifikan positif terhadap penerimaan pajak.

Pengaruh penerapan $e$-tax terhadap penerimaan pajak yang didapat sebesar $6,448>1,98498$ dan memiliki nilai signifikan sebesar $0,000<0,05$. Hal ini berarti $\mathrm{H}_{2}$ diterima dan dapat dikatakan bahwa penerapan $e$-tax berpengaruh signifikan positif terhadap penerimaan pajak.

\section{Uji Simultan (F)}

Uji $\mathrm{F}$ bertujuan untuk mengetahui apakah variabel independen secara simultan atau bersama-sama mempengaruhi variabel dependen secara signifikan. Pengujian ini menggunakan uji $F$ yaitu membandingkan $F_{\text {hitung }}$ dengan $F_{\text {tabel. }}$.

Didapatkan hasil nilai $F_{\text {hitung }}$ adalah sebesar 66,096 lebih besar dari $F_{\text {tabel }}$ yaitu 2,70 dengan nilai signifikan sebesar 0,000 yang artinya nilai signifikan kurang dari 0,05 , maka dapat disimpulkan bahwa penerapan teknologi informasi dalam sistem administrasi perpajakan modern, profesionalisme account representative dan penerapan e-tax secara simultan berpengaruh signifikan positif terhadap penerimaan pajak.

\section{Diskusi Hasil dan Pembahasan}

Pengaruh Penerapan Teknologi Informasi dalam Sistem Administrasi Perpajakan Modern terhadap Penerimaan Pajak

Hasil uji hipotesis $\mathrm{H}_{1}$ menunjukan bahwa variabel penerapan teknologi informasi dalam sistem administrasi perpajakan modern tidak berpengaruh terhadap penerimaan pajak. Dengan tingkat signifikansi 0,198 lebih besar dari $\alpha=$ 0,05 dan menunjukan nilai koefisien beta yang dihasilkan bernilai negatif sebesar -0,153. Sehingga hipotesis $H_{1}$ dapat dikatakan bahwa penerapan teknologi informasi dalam sistem administrasi perpajakan modern tidak berpengaruh terhadap penerimaan pajak.

Teknologi informasi adalah suatu teknologi yang digunakan untuk mengolah data, termasuk memproses, mendapatkan, menyusun, menyimpan, memanipulasi data berbagai cara untuk menghasilkan informasi yang berkualitas, yaitu informasi yang relavan, akurat, dan tepat waktu yang digunakan untuk keperluan pribadi, bisnis, dan pemerintahan yang merupakan aspek strategis untuk pengambilan keputusan. Dalam perpajakan diharapkan teknologi informasi dalam sistem administrasi perpajakan modern dapat memberikan kontribusi dalam hal penerimaan pajak yang memungkinkan terjadinya peningkatan penerimaan pajak.

Pengaruh profesionalisme account representative terhadap penerimaan pajak. Hasil uji hipotesis $\mathrm{H}_{2}$ menunjukan bahwa variabel profesionalisme account representative berpengaruh signifikan dengan arah yang positif terhadap penerimaan pajak. Ini dilihat dari tabel 4.15 dengan tingkat signifikansi 0,000 lebih kecil dari $\alpha=0,05$ dan menunjukan nilai koefisien beta yang dihasilkan bernilai positif sebesar 0,474 . Sehingga hipotesis $\mathrm{H}_{2}$ dapat dikatakan bahwa profesionalisme account representative berpengaruh terhadap penerimaan pajak.

Pengaruh aplikasi $e$-tax terhadap penerimaan pajak menunjukan angka signifikansi sebesar 0,000. Dengan demikian maka $\mathrm{H}_{3}$ diterima karena nilai 
signifikan lebih kecil dari 0,05 dan penerapan aplikasi $e$-tax berpengaruh terhadap penerimaan pajak.

Pengaruh penerapan teknologi, profesionalisme account representative dan Aplikasi E-Tax secara simultan terhadap penerimaan pajak. Berdasarkan hasil pengujian statistik $\mathrm{F}$ variabel independen berpengaruh secara simultan terhadap variabel dependen apabila nilai $\mathrm{F}_{\text {hitung }}<\mathrm{F}_{\text {tabel. }}$. Dalam penelitian ini, $\mathrm{F}_{\text {hitung }}$ $66,096>F_{\text {tabel }} 2,70$, maka variabel independen (Penerapan Teknologi Informasi Dalam Sistem Administrasi Perpajakan Modern dan Profesionalisme Account Representative) berpengaruh secara simultan terhadap Penerimaan Pajak.

\section{KESIMPULAN}

Untuk melihat apakah ada pengaruh Penerapan Teknologi Informasi, Profesionalisme Account Representative dan Aplikasi E-Tax terhadap Penerimaan Pajak, maka dilakukanlah penelitian ini. Adapun tempat yang tepat untuk melakukan pengamatan tersebut, maka yang dipilih adalah Kantor Pelayanan Pajak Pratama Kebayoran Baru Tiga. Sampel yang dipilih sebanyak 100 responden dengan metode random sampling. Adapun hasil penelitian dan pengujian data serta didukung oleh kuisioner yang memiliki validitas yang tinggi serta data data yang otentik, maka dapat disimpilkan bahwa :

1. Penerapan teknologi informasi tidak mempengaruhi penerimaan pajak. Terlihat T hitung sebesar 1,297 < T tabel 1,98498 dan signifikansi 0,198 > 0,05. Hal ini berarti Penerapan teknologi informasi bukanlah salah satu penentu peningkatan penerimaan pajak. Hal ini diduga karena tidak semua wajib pajak dapat menerima penggunaan teknologi informasi dalam lingkup perpajakan.

2. Profesionalisme account representative memiliki pengaruh positif dan signifikan pada penerimaan pajak. Terlihat $\mathrm{T}$ hitung sebesar 4,623 > T tabel 1,98498 dan signifikansi $0,000<0,05$. Hal ini dapat dikatakan bahwa profesionalisme account representative merupakan salah satu penentu meningkatnya penerimaan pajak. Dikarenakan adanya kehadiran Account Representatife yang memiliki profesionalisme yang tinggi dan memiliki kapabilitas, hal ini menjadi acuan dalam mengoptimalkan pendapat negara melalui penerimaan pajak dan memaksimalkan kepatuhan wajib pajak. 


\section{DAFTAR PUSTAKA}

Agustin, Aiven. (2016). Pengaruh Profesionalisme Account Representative Terhadap Tingkat Kepatuhan Wajib Pajak (Studi Kasus Pada KPP Pratama Bndung Cibeunying). Skripsi pada Fakultas Ekonomi : Universitas Widyatama.

Agustini, Putu Eka Pratiwi dan Ni Luh Supadmi. (2016). Pengaruh Modernisasi Sistem Administrasi dan Sanksi Perpajakan Pada Kepatuhan Wajib Pajak. EJurnal Akuntansi Universitas Udayana. Vol.15 No.1 April 2016 : 27-54.

Ari, Novita Sari dkk. (2015). Pengaruh Kualitas E-Tax Terhadap Kualitas Pelayanan dan Kepatuhan Wajib Pajak (Studi atas Wajib Pajak Pada Dinas Pendapatan Daerah Kota Malang). Jurnal Administrasi Bisnis - Perpajakan (JAB) Vol. 6 No.1.

Arifin, Adhitya Febrian. (2015). Pengaruh Modernisasi Sistem Administrasi Perpajakan, Kesadaran Perpajakan, Sanksi Pajak dan Pelayanan Fiskus Terhadap Kepatuhan Wajib Pajak Orang Pribadi Pada Kantor Pelayanan Pajak Pratama. Perbanas Review Vol. 1 No.1 November 2015.

Aryati, Titik dan Lidwina Ribka Putritanti. (2016). Pengaruh Pemanfaatan Teknologi dan Modernisasi Sistem Administrasi Perpajakan Terhadap Kepatuhan Wajib Pajak Orang Pribadi. Jurnal Riset Akuntansi dan Keuangan, Vol.4 No.3.

Ayu, Dara Mentari. (2016). Analisis Pengaruh Penerapan Metode E-Billing dan Manual Wajib Pajak Badan Terhadap Penerimaan Pajak (Studi Pada Kantor Pelayanan Pajak Penanaman Modal Asing Enam, Jakarta). Fakultas Ekonomi dan Bisnis : Universitas Lampung. Bandar Lampung. Diakses tanggal 24 November 2017.

Castrio. (2016). Pengaruh Kemauan, Kesadaran, Pengetahuan dan Pemahaman, Kualitas Layanan dan Keefektifitasan Sistem Membayar Pajak Terhadap Kepatuhan Pajak dengan Penerapan E-Tax Sebagai Variabel Moderasi (Survey pada Wajib Pajak Orang Pribadi di Daerah Istimewa Yogyakarta). Skripsi pada Fakultas Ekonomi dan Bisnis : Universitas Muhammadiyah Yogyakarta.

Fahrudin, Muh Zuhri. (2015). Mengoptimalisasi Perolehan Pajak Dengan Meningkatkan Kinerja Lembaga Dan Pembaharuan Sistem Regulasi Pajak. Jurnal Pasca Sarjana UNS. Vol.3 No.2 Juli-Desember.

Fatmawati, Endang. (2015). Technology Acceptance Model (TAM) Untuk Menganalisis Penerimaan Terhadap Sistem Informasi Perpustakaan. Jurnal Iqra Vol.09 No.1 Mei 2015

Ghazali, Imam. (2013). Aplikasi Analisis Multivariate dengan Program IBM SPSS 21. Edisi 7, Universitas Diponegoro, Semarang. 2013.

Hakim, Muhammad Malik. (2016). Analisis Model Penerimaan Pengguna Sistem Pelaporan Pajak Online. Jurnal Simetris Vol.7 No.1 April 2016

Jubaedah, Idah. (2015). Pengaruh Pemanfaatan Teknologi Informasi Terhadap Implementasi Sistem Informasi Direktorat Jenderal Pajak dan Implikasinya Terhadap Kinerja Pegawai (survey pada KPP Pratama di Wilayah 
Bandung). Fakultas Ekonomi : Universitas Komputer Indonesia, Bandung. Diakses Tanggal 8 November 2016.

Kiswara, Danar dan I Ketut Jati. (2016). Pengaruh Penerapan E-Filling dan Peran Account Representative Terhadap Pencitraan Otoritas Pajak dan Kepatuhan Wajib Pajak. E-Jurnal Akuntansi Universitas Udayana Vol.15 No.1 April 2016, hal.349377

Kuncoro, Mudrajad. (2013). Metode Riset Untuk Bisnis \& Ekonomi. Edisi 4, Erlangga. Yogyakarta.

Mardiasmo. (2013). Perpajakan Edisi Revisi. Edisi 17, Andi, Yogyakarta.

Maria, Delli. (2013). Pengaruh Modernisasi Sistem Administrasi Perpajakan Terhadap Tingkat Kepatuhan Pengusaha Kena Pajak di Kantor Pelayanan Pajak Pratama Bandar Lampung. Jurnal Bisnis Darmajaya Vol.1 No.1 Maret 2013.

Nofryanti dan Anita Charlina. (2014). Pengaruh Modernisasi Perpajakan dan Sistem Administrasi Perpajakan Terhadap Penerimaan Pajak Penghasilan 21 (Studi Kasus KPP Pratama Bogor). Jurnal Ilmiah Akuntansi Universitas Pamulang Vol.1 No.2 Januari 2014, hal. 110-123.

Nurabiti, Ellyn dkk. (2016). Pengaruh Implementasi Sistem Eleketronik Bagi Wajib Pajak Terhadap Kualitas Pelayanan Administrasi Perpajakan (Studi pada Wajib Pajak Terdaftar di KPP Pratama Malang Utara). Jurnal Perpajakan (JEJAK) Vol.9 No.1.

Pohan, Chairil Anwar. (2014). Pembahasan Komprehensif Pengantar Perpajakan Teori dan Konsep Hukum Pajak. Edisi Ali, Mitra Wacana Media, Jakarta, 2014.

Priyatno, Duwi. (2016). Belajar Alat Analisis Data dan Cara Pengolahannya dengan SPSS. Edisi 1 Cetakan Pertama, Gava Media, Yogyakarta.

Rachman, Nanra. (2016). Pengaruh Pemanfaatan Teknologi Informasi, Kapasitas Sumber Daya Manusia dan Pengendalian Intern Terhadap Keterhandalan Pelaporan Keuangan (Studi Pada Dinas Pengelolan Keuangan dan Aset Daerah Kota Bandung). Fakultas Ekonomi dan Bisnis : Universitas Pasundan. Bandung. Diakses tanggal 8 November 2016.

Rahayu, Siti Kurnia. (2013). Perpajakan Indonesia Konsep dan Aspek Formal. Edisi Pertama Cetakan Ke-2, Graha Ilmu, Yogyakarta.

Said, Anies M Basalamah dkk. (2016). Pemisahan Fungsi Account Representative dan Penerimaan Pajak yang Lebih Baik. Kajian Ekonomi Keuangan Vol.20 No.1 April 2016.

Saputra, Rahadian dkk. (2014). Analisis Penggunaan Aplikasi Sistem Informasi Direktorat Jenderal Pajak (SIDJP) dan Kinerja Pegawai (Studi Pada KPP Pratama Surabaya Gubeng). Jurnal Perpajakan Vol.3 No.1 November 2014.

Sugiyono. (2016). Metode Penelitian Kuantitatif, Kualitatif dan $R \& D ”$, Cetakan Ke-23, Alfabeta, Bandung.

Sulistyorini, Murniati dkk. (2017). Pengaruh Penggunaan Sistem Administrasi ERegistration, E-billing, E-SPT dan E-Filling Terhadap Kepatuhan Wajib Pajak (Studi Pada Wajib Pajak Orang Pribadi Di RSUD Dr. Moewardi Surakarta). Fakultas Ekonomi : Universitas Islam Batik. Surakarta. Diakses tanggal 9 April 2017.

Tampubolon, Kristina Paradias Br. (2015). Pengaruh Account Representative dan Pengetahuan Wajib Pajak Badan Terhadap Kepatuhan Wajib Pajak Badan (Studi Pada Kantor Pelayanan Pajak Pratama Bandung Karees). Fakultas Ekonomi dan Bisnis: Universitas Telkom. Diakses tanggal 10 April 2017.

Tania, Finny Rachdianti dkk. (2016). Pengaruh Penggunaan E-Tax terhadap Kepatuhan Wajib Pajak. Jurnal Perpajakan (JEJAK) Vol. 11 No.1 2016. 
Yuditya, Y Adiwijaya. (2014). Pengaruh Kompetensi Account Representative dan Independensi Account Representative Terhadap Strategi Pengamanan Penerimaan Pajak Kanwil DJP DIY. Fakultas Ekonomi : Universitas Atmajaya. Yogyakarta. Diakses tanggal 10 April 2017.

Keputusan Direktur Jenderal Pajak Nomor KEP-178/PJ/2004.Tentang Cetak Biru (Blue Print) Kebijakan Direktorat Jenderal Pajak Tahun 2001-2010

Peraturan Direktur Jenderal Pajak PER-03/PJ/2015 Tentang Penyampaian Surat Pemberitahuan Elektronik

Peraturan Direktur Jenderal Pajak PER-26/PJ/2014 Tentang Sistem Pembayaran Pajak Secara Elektronik

Peraturan Direktur Jenderal Pajak PER-37/PJ/2010 Tentang Kebijakan Tata Kelola Teknologi Informasi dan Komunikasi DJP

Peraturan Menteri Keuangan No. 206.02/PMK.01/2014 Tentang Organisasi dan Tata Kerja Instansi Vertikal Direktorat Jenderal Pajak.

Peraturan Menteri Keuangan Republik Indonesia PMK-79/PMK.01/2015 Tentang Account Representative Pada Kantor Pelayanan Pajak Tentang Jenis Pajak Daerah Yang Dipungut Berdasarkan Penetapan Kepala Daerah Atau Dibayar Sendiri Oleh Wajib Pajak

Undang-Undang Republik Indonesia Nomor 16 tahun 2009 Tentang Ketentuan Umum dan Tata cara Perpajakan

Undang-undang RI No.19 Tahun 2016 Tentang Informasi dan Transaksi Elektronik

www.bps.go.id

www.google.com

www.pajak.go.id

https://terompahku.wordpress.com/2011/11/19/direktorat-teknologi-informasi-

perpajakan-mewujudkan-integritas-dan-profesionalisme/ 